\title{
Analysis of Tukul Arwana's Speech Acts in a Bukan Empat Mata Programe in Trans 7: A Pragmatic Study
}

\author{
Ansetry $^{1(*)}$, Abdurrahman $^{2}$, Ngusman Abdul Manaf $^{3}$ \\ ${ }^{1}$ Indonesian Language and Literature Education Study Program, Postgraduate Universitas Negeri Padang, Indonesia \\ ${ }^{2} 1$ st Advisor, Abdurahman, Lecture of Language and Art Faculty, Universitas Negeri Padang, Indonesia \\ ${ }^{3} 2 n d$ Advisor, Ngusman Abdul Manaf, Lecture of Language and Art Faculty, Universitas Negeri Padang, Indonesia \\ "Corresponding author. Email: ansetry100789@gmail.com
}

\begin{abstract}
The purpose of this study is to describe the use of localized speech acts, illocutionary (assertive, directive, commissive, expressive, and declarative), and perlocution used by TukulArwana in the Non-Four Eyes event in Trans7. This research is a qualitative study using descriptive methods. Data collection techniques used in this research are the recording, listening and note taking techniques. Furthermore, the data are analyzed by translating speech into written form, classifying based on the type of speech act into tabular form, describing speech that has been classified, making discussion, and concluding. The results showed that out of 576 TukulArwana's speeches in several episodes of the Non-Four-Eyes program that were observed, there were 147 speeches which included locus speech acts, and illocutionary speech acts which consisted of assertive, directive, expressive, and commissive speech acts. The most widely used form of speech acts is directive and expressive illocutionary speech acts. The least speech acts are commissive speech acts, and those that are not found are declarations and speech acts.
\end{abstract}

Keywords: Speech acts, pragmatic studies

\section{INTRODUCTION}

Speech act is one of the social events involved in the communication process. The communication that occurs between the speaker and the speech partner really requires good cooperation so that assumptions don't occur in a conversation. However, often the conversations that occur are the opposite, there is no good collaboration between the speaker and the speech partner. When speaking they do not pay attention to the situation and speech time. In addition, the speaker must also pay attention to politeness in speaking so that the speaker does not feel offended by the speech spoken.

One of the communication media owned by the public is television. Television broadcasts have a very big influence on human life, so that he is able to change attitudes, opinions, and behavior of a person in a relatively short span of time. Of the many existing television stations, Trans7 is a television station that is quite popular with the public. One of the shows that aired on Trans7 was Bukan Emat Mata. This program is broadcast every Monday to Friday at 21:30 WIB, which is hosted by Tukul Arwana. Tukul Arwana is a person who has a humorous nature, so this event is sought after by many people because it can entertain. One of the most famous sentences in the event is back to the laptop. In addition, the program does not show the eyes of an adult guest star, and watched by adults, often the speech delivered by Tukul is adult speech. When compared to other TV shows, the program does not show the Bukan Emapat Mata is a more real program by discussing the real life of Indonesian celebrities.

The Bukan Empat Mata was a continuation of the Empat Mata program. This program was once censored by the Indonesian broadcasting commission, because in this event Tukul Arwana often issued speeches that were not polite, even offending a certain person or institution. Besides that, Tukul Arwna also often issued dirty or vulgar speech. This is stated in the broadcasting law No.32 / 2002 / article5 (b) which states that broadcasts are prohibited from displaying elements of violence, obscene, gambling, narcotics abuse, and illegal drugs.

The broadcast also violates Article 13 paragraph 1 Broadcast Program Standards which states that broadcasters must not present the use of language, or swear words that have a tendency to insult, humiliate human beings, have meaning dirty or obscene, obscene, vulgar, and insult religion and God. Therefore the program was censored by Indonesian broadcasters.

Today, the Empat Mata program is changed to the Bukan Empat Mata program. The concept of this event is the same as the previous event, each episode has a different theme, and also presents a different guest star. This program features a question and answer session between Tukul Arwana and the guest stars. Every question 
and answer session of Tukul Arwana does not pay attention to how to speak well and correctly, so that when the guest stars answer their questions, Tukul Arwana always interrupts the conversation. In fact, what was delivered by the guest stars who were present were always interrupted by Tukul Arwana. Speech that occurs between tukul Arwana with guest stars is a form of speech acts. Therefore Tukul Arwana's speech acts can be investigated through pragmatic studies.

Rahardi (2005: 35) "speech acts are concrete manifestations of language functions, which are the foundation of pragmatic analysis." In every communication humans convey information that can be in the form of thoughts, ideas, intentions, feelings, and emotions directly. According to real experience, the language always appears in the form of individual actions or speech acts. Therefore every study of language structure must start from the assessment of speech acts.

Wijana and Rohmadi (2010: 21) argued "locus acts are speech acts to state something." Locution speech acts are speech acts that can be easily understood by the speech partners, because locus speech acts only state something that has meaning so that it can be understood by partners said. Ibrahim (2012: 13) divides illocutionary speech acts into six categories, namely: (1) effective, (2) fictional, (3) constant, (4) directive, (5) commissive, and (6) expressive.

\section{METHOD}

In this study, the method used is descriptive method, because the implementation of this research is to describe, analyze, and interpret Tukul Arwana's speech acts at the Bukan Empat Mata in the Trans 7. Moleong (2001:4) explains "Qualitative research is carried out in a natural setting or in the context of a unity". Qualitative research conducted to find out the results in the form of verbal data, pictures, but not number. The object of this research is Tukul Arwana's speech act in Bukan Empat Mata in Trans 7. This program is broadcast every Monday to Friday at 21:30 WIB. The event always has a different theme. The research themes are as follows: (1) "Forever Love Song", (2) "Marriage, Who's Afraid", (3) "Obsession", (4) "Sleeping Flowers", (5) "Scary Places", (6) ) "Life Must Go On", and (7) "My Couple, My Partner". The theme was taken, due to the phenomena that often occur in daily life, related to events that are being discussed hotly in the community. The data is taken for one week in a row, because if it is taken randomly there will be changes in speech made by Tukul Arwana. For example, on Eid alFitr, the speech that is spoken will be more polite when compared to normal days.

This research instrument is a measuring tool carried out to obtain the required data. In this study, the researchers became the real physical instruments of the researchers themselves using recorders such as cellphones, and television as a medium of communication to record the shows of Bukan Empat Mata. This is in line with the opinion Sugiyono (2012: 60) states that the researcher is a key instrument because as a human instrument, the researcher functions is to set the focus of research, select data sources, collect data, identify data, classify data, analyze data and make conclusions. Data collection techniques used in this research are the recording, listening and note taking techniques. Furthermore, the data are analyzed by translating speech into written form, classifying based on the type of speech act into tabular form, describing speech that has been classified, making discussion, and concluding.

\section{RESEARCH RESULTS AND DISCUSSION}

The description of the data is to describe the research data that has been collected. In this chapter the results of research data are presented about the speech acts of Tukul Arwana in the Bukan Empat Mata in Trans7 program. After all data is collected, it is processed by describing and grouping data according to its type. This grouping is done to find out the types of speech acts, namely locus acts, illocutionary acts consisting of assertive, directive, commissive, expressive, and declarations as well as speech acts of percocution.

The data of this study were taken during one week of the broadcast program of Bukan Empat Mata in Trans7. The data of this study consisted of 576 utterances during one week of screening. Data that includes locus speech acts found 1 utterance, illocution consisting of assertive, directive, commissive, expressive, and declaration consisting of 147 utterances from 576 Tukul Arwana's utterances.

\section{Locus Speech Acts}

Locus speech acts are speech to express something that has meaning and can be easily understood by the speech partner. Speech expressed can be immediately captured its meaning. The form of the speech is seen in the speech that singed by a Malaysian singer, who sings Sheila Majid!

'Singer Sheila Majid from Malaysia!' (Tm1, 32)

Context: Tukul Arwana talked to Odi Agam and the studio audience about Shaila Majid

The meaning of the speech above is Tukul telling about Malaysian singers. The speech quote above Tm1 (32) explained to the speech partner that the singer who came from Malaysia named Sheila Majid. At that time Tukul Arwana gave a question to Odi Agam. The speech has a meaning that Tukul Arwana states Sheila Majid is a singer who came from Malaysia, and is easy to understand.

\section{Illocutionary Speech Acts}

The illocutionary speech acts analyzed consist of (a) assertive speech acts, (b) directive speech acts, (c) commissive speech acts, (d) expressive speech acts, and (e) declaration speech acts. The speech is analyzed the form and meaning contained therein. More details can be seen as follows:

a. Assertive

Assertive illocutionary speech acts involve the speech partner directly that the utterances they express are true. 
The utterances are expressed through the expressed utterances. The speech acts found in Tukul Arwana's speech at the Bukan Empat Mata program are giving suggestions, complaining, expressing opinions, and stating.

\section{1) Give a Proposal}

The speech act of giving a proposal is a speech that intends to provide input or provide advice to the speech partner, so that the speech partner can directly assess the speech. The speech partner can decide to accept or reject the advice given. The form of assertive speech acts gives suggestions as seen in the following statements:

How do you see this pregnant person? There are tips while ules his stomach say Subhanallah!

'Ola how to see someone pregnant? The solution is to

hold his stomach while saying Subhanallah! '(TM2,

54)

Context: Ola Ramlan was silent when he saw someone pregnant, and he felt a little sad because he saw that.

The meaning of Ola Ramlan directly holds Natasya's stomach while saying subhannallah. Eating the speech, Tukul Arwana proposed to Ola Ramlan to hold the belly of Natasya Rizki who was pregnant while resting. In the speech above, Tm2 (54) is an assertive speech act giving a proposal. The context of this speech occurs when Tukul Arwana arrives a guest, Natasya Rizki who is pregnant, then Tukul Arwana gives Ola a suggestion to get pregnant quickly by stroking Natasya's stomach and Ola Ramlan also makes a proposal given by Tukul.

\section{2) Complaining}

Complaining is an expression spoken by a speaker where he feels something he doesn't like. Usually speakers expect sympathy towards the speech partner. The form of speech acts can be seen in the speech below:

The wife is everything, one cooks a thousand tastes!

'My wife cooks thousands of tastes!' (Tm7, 26)

Context: audience, Arumi, Emil, Pepi, and Ola Ramlan laughed at Tukul Arwana's speech so that the atmosphere became noisy.

The meaning of Pepi and Ola Ramlan laughed at Tukul Arwana's words. Tukul Arwana said that he did not like his wife Susi's cooking. The quotation above, in the form of assertive speech acts, complains. The meaning of this speech took place when Tukul gave a question to Arumi Bachsin about her activities after marriage. One of the activities mentioned is cooking. Then Tukul Arwana complained that his wife could not cook.

\section{3) Expressing Opinion}

Expressing opinions is the utterance expressed by the speaker that comes from the thoughts of the speaker himself so that the speech partner can judge whether or not the speech is correct. The form of speech acts can be seen in the speech below

Viewers, many think that a dream is just a bedtime but many people think that this has meaning, keep dreaming!
'Audience, a dream is just a sleeping flower but there are still those who think it is real. Keep dreaming! '(Tm4, 80)

Context: Tukul Arwana will close the Non-Eyes program, accompanied by Vega, Ola Ramlan, Pepi, Cristy Yulia, Endang Widiastuti, and Lisa Jarby

The meaning of the speech quote above is a form of speech act giving an opinion. The meaning of this speech when Tukul Arwana ended the program is not Four Eyes. At the end of the program, Tukul always concludes with the theme of the evening. When closing the program he was accompanied by all the guest stars.

4) States

Stating is the utterance expressed by the speaker to state something to the speech partner. The assertive speech act form states can be seen in the following speech:

As I'm looking for my wife and I'm not looking for adventurous ones, the important thing is to cover my shortcomings!

I am looking for a wife who is not strange, what is important can cover my shortcomings! '(Tm2, 25)

Context: audience laughs.

Meaning of Beat Arwana gave his opinion on the answer given by the guest star Saskia Sungkar, the audience applauded. The speech quote above is a form of speech act stated. The speaker says to the speech partner that if he looks for a wife, he does not look for various things, but rather looks for a wife who can cover his shortcomings.

\section{b. Directive}

The directive speech act is the speech act used by the speaker to state something so that the speech partner does something delivered by the speaker. The speech act is expressed as asking, ordering, and giving advice.

1) Asking

Asking for is the utterance expressed by the speaker to expect something from the speech partner. Speakers expect that the speech partner does something requested by the speaker.

Greetings first for the family!

'Greetings to the family!' (Tm5, 80)

Context: silent audience.

The meaning of Tukul Arwana has won the quiz winner, Mr. Sadam from Bengkulu, and Tukul asked the father to go up on the stage and told to send greetings to the brothers at home. The speech quote above is a form of speech act asking. The context of this speech when Tukul Arwana has won the quiz winner namely Mr. Santoso from Bengkulu and Tukul Arwana asked Mr. Santoso to greet his family. Mr. Santoso did it too.

\section{2) Give advice}

Giving advice is speech that is expressed by a speaker who intends to give a good lesson. The speaker hopes that the speech can be well received by the speech partner. The 
form of speech act provides advice seen in the speech below:

Viewers, don't be ashamed to express love even if it's just a song, because love is the most beautiful thing!

'Audience, don't be shy to express love with songs, because love is a beautiful thing!' (Tm1, 67) Eyes.

Context: Tukul Arwana closes the program Not Four

The meaning of the speech quote above is a form of speech act giving advice. The purpose of the speech is where the speaker expects that the speech partner is not shy about expressing his feelings through a song, because love can be expressed through songs because love is a very beautiful feeling. For this reason, the speaker hopes that the speech partner can express his feelings through a song. Tukul Arwana closed the program, not Four Eyes.

3) Govern

Governing is an expression expressed by the speaker to the speech partner and the speaker expects the speech partner to do what the speaker wants. In addition, speakers also expect action from speech partners. The directive directive action forms can be seen in the speech below:

Okay Pepi now open the box, maybe the viewers can guess later I will give my signature, Ola, and Pepi!

'Well Pepi opened the box, maybe the audience could guess for those who can guess I will give my autograph, Ola, and Pepi!' (Tm7, 72)

Context: Tukul Arwana will have Pepi open the guess box that night. Pepi opened it and it turned out that the box contained a guitar. Tukul stands and Ola is beside Tukul. Tukul raises his hand holding a marker to sign the prize.

The meaning of the speech quote above is a form of governing speech act. The context of this speech occurs when Tukul Arwana will tell Pepi to open the guessing box that night. Pepi opened it and it turned out that the box contained a guitar.

\section{CONCLUSION}

Based on the description and analysis of the data conducted on Tukul Arwana's speech acts in the Bukan Empat Mata program, it can be concluded that the form of speech acts used are localized speech acts and illocutionary speech acts consisting of assertive, directive, commissive, and expressive. Tukul Arwana's utterances that occurred in the Non-Eye of the Event contained 576 speeches. Data including locus speech acts, and illocution which consists of assertive, directive, expressive, and commissive as many as 147 utterances.

The most widely used form of speech acts is the directive and expressive illocutionary speech acts. This happened because in his speech Tukul Arwana often ordered his friend to be a companion in hosting the program not to be Four Eyes. In addition, he also always praised the guest stars who were invited to the event. The speech should indeed be spoken in a talkshow to create a sense of security for invited guests. The talkshow is a talk show between the host and someone invited to the event, one of which is the Bukan Empat Mata.

Locus speech acts were found in 2 utterances, namely on the first and second themes, each with one utterance. Assertive speech acts are used as many as 16 utterances, namely the first theme 1 utterance, the second theme 5 utterances, the third theme 1 utterance, the fourth theme 2 utterances, the fifth theme 1 utterance, the sixth theme 2 utterances, and the seventh theme 4 utterances. The directive speech acts were found as many as 64 utterances, namely on the first theme 8 utterances, the second theme 9 utterances, the third theme 22 utterances, the fourth theme 7 utterances, the fifth theme 4 utterances, the sixth theme 8 utterances, and the seventh theme 6 utterances. Commissive speech acts were found in 5 utterances, namely in the second theme 1 utterance, the third theme 2 utterances, the fifth theme 1 utterance, and the sixth theme 1 utterance. Expressive speech acts were found as many as 60 utterances, namely on the first theme 12 utterances, the second theme 7 utterances, the third theme 10 utterances, the fourth theme 7 utterances, the fifth theme 4 utterances, the sixth theme 12 utterances and the seventh theme 8 utterances. Declaration speech acts not found. Perlokusi speech acts are also not found at all. So the speech acts that are often found are illocutionary speech acts namely directive and expressive speech acts because Tukul Arwana often orders his friends to submit quiz instructions in the event. And he also always praised the guest stars who were invited to the show Bukan Empat Mata. The least speech acts are commissive speech acts and those that are not found are declarations and speech acts.

\section{REFERENCES}

[1] Ibrahim, A.S. (2012). Kajian Tindak Tutur. Surabaya: Usaha Nasional.

[2] Moleong. L.J. (2001). Metodologi Penelitian Kualitatif. Bandung: Remaja Rosdakarya.

[3] Rahardi, K. (2005). Pragmatik: Kesantunan Imperatif Bahasa Indonesia. Jakarta: Erlangga.

[4] Sugiyono. (2012). Memahami Penelitian Kualitatif. Bandung: Alfabeta.

[5] Wijana, I.D.P \& Rohmadi. (2010). Analisis Wacana Pragmatik. Surakarta: Yuma Pustaka. 